\title{
METODIKA JADRANKE DAMJANOV - OSVIJEŠTAVANJE DOSLOVNOG VIDA OSJETILNOG OPAŽANJA
}

\author{
Marko Tokić \\ Odsjek za filozofiju, Filozofski fakultet, \\ Sveučilište u Zagrebu, Hrvatska \\ tokicmarko@yahoo.co.uk
}

\begin{abstract}
Polazeći od polemike koja se razvila između Matka Peića i Damjanovinih učenika u Telegramu 1961. godine, želi se rasvijetliti smisao Damjanovine metodike nastave povijesti umjetnosti. Jadranka Damjanov smatra da je svrha umjetničkog odgoja osvijestiti ono što se opaža. Obrazloženje je ponudila rezultatima elektronistamografskih istraživanja, koje je sprovela na ispitanicima koji su promatrali moderna umjetničko-likovna djela. Zaključila je da je umjetnost osjetilno razotkrivanje mjere, koje s jedne strane ostvaruje gledatelj, a s druge strane umjetnik. Teza je rada da se Damjanova svojim zaključkom u bitnom udaljava od općeprihvaćenog shvaćanja umjetnosti, prema kojemu je za umjetnost odredbeno samo proizvođenje svojstveno umjetniku.
\end{abstract}

Ključne riječi: opažanje, oči, elektronistamografija, odgoj (obrazovanje), svijest, umjetnost.

\section{Radioničarima...}

U hrvatskim srednjim školama kroz prvu polovicu dvadesetog stoljeća nastava likovne umjetnosti - izuzev klasičnih gimnazija - svodila se na satove slikanja i crtanja.* Jedinstven plan i program likovne umjetnosti za sve gimnazije uveden je 1960. godine. S jedne je strane

* Ovaj tekst je rezultat rada na projektu »Filozofski i odgojni aspekti suosjećanja«, koji je proveden uz potporu Sveučilišta u Zagrebu (2016.) na Filozofskom fakultetu u Zagrebu, a u okviru znanstvene djelatnosti Znanstvenog centra izvrsnosti za integrativnu bioetiku. 
pretpostavljao poticanje učenika na osjećanje, razumijevanje i doživljavanje umjetničkog djela, a s druge je strane pretpostavljao usvajanje teorijskih spoznaja iz povijesti umjetnosti, s ciljem razvoja emocionalnog života učenika (PV, 1960, 173-175). Takav plan i program prvenstveno je osmislio Milan Prelog koji je - u želji da se njegove ideje sprovedu u praksi - obvezao Jadranku Damjanov na pisanje udžbenika i konkretiziranje didaktičko-metodičkog pristupa.

Unatoč tome što su se mnogi u početku protivili reformi, činjenica je da su je Damjanovini učenici dobro prihvatili. To prije svega posvjedočuju njihovi radovi u školskom godišnjaku Umjetnost $i$ mi, koji je izlazio od 1960. do 1968. godine. Oduševljenje učenika novim oblikom nastave likovne umjetnosti dokazuje i njihova polemika s Matkom Peićem.

Matko Peić u jednom broju Telegrama negativno kritizira Damjanovinu metodiku, podcjenjujući gimnazijalce koji pišu za školski godišnjak Umjetnost $i$ mi:

\begin{abstract}
»Zasad je dovoljno konstatirati da je jučer intervencija povjesničara umjetnosti, u mnogo slučajeva, bila dobrodošla u nastavi likovnog odgoja, jer je čestoput teorija oživjela mjestimično umrtvljenu praksu. No danas, kad kritički promatramo situaciju, opažamo da ta ista teorija često umrtvljava pa i likvidira praksu. Javlja se tip učenika koji ništa u umjetnosti ne umije, ali sve o umjetnosti zna. Formira se za umjetnički fenomen najopasniji tip - mladi čovjek koji sam ne osjeća, nego se zabavlja time da misli o tom što su drugi osjećali. Javlja se jednom riječju tip nekog malog filozofa umjetnosti.« (Peić, 1961a, 5)
\end{abstract}

Gimnazijalci su odgovorili na članak Matka Peića u jednom od narednih brojeva Telegrama. Poručili su da im nastava iz povijesti umjetnosti ne služi za brušenje intelekta, nego im omogućuje da dožive sebe i svijet oko sebe. Prema njihovom mišljenju nema smisla učiti crtati u srednjoj školi ako se namjesto toga može učiti gledati te tako stjecati i produbljivati doživljaj osjetilne stvarnosti. A ideju o umjetničkom odgoju kao činu produbljivanja doživljaja onoga vidljivog mogli su imati samo zato što su, zahvaljujući načinu na koji je Jadranka Damjanov izvodila nastavu, naučili gledati:

»Ta mi volimo povijest umjetnosti upravo zbog toga što nas je ona naučila vidjeti i doživjeti tamo gdje prije nismo ništa vidjeli i osjećali.« (Janda et al., $1961,5)$

Čini se stoga da su učenici doživjeli likovnu umjetnost kao svojevrsni lijek kojim se usađuje vid u slijepe oči. No prema Damjanovinu 
shvaćanju taj i takav vid njima nije nedostajao u tom smislu da ga oni nisu dotada imali. Radilo se zapravo samo o razotkrivanju izvornog $\mathrm{i}$ neposrednog osjećanja koje je čovjeku urođeno.

Ona im nije pričala priče o umjetnicima niti o zanimljivostima oko pojedinih umjetničkih djela; nije zahtijevala niti da umiju učeno verbalizirati svoja estetička iskustva. Jer bi na taj način nasljedovali ideal intelektualca odlikovanog duhom devetnaestog stoljeća, te stoga ne bi mogli na autentičan način izraziti sebe. Još manje bi u neposrednom dodiru s umjetnošću uspjeli otkriti suvremene vrijednosti duha čovječanstva:

»... ne učimo povijest umjetnosti zbog mogućnosti otmjene konverzacije, niti pripreme za kritičarsku praksu. Mi ne želimo biti mali filozofi! [...] Stara škola 19. stoljeća bila je ona koja je favorizirala jedan određeni tip učenika, npr. one koji znaju latinske stihove, matematiku i povijesne činjenice, oni su tada bili pametni, a svi ostali glupi. Zar da u novoj školi cijenimo više one učenike koji iskaču svojim likovnim talentom, za koje uostalom postoje stručne škole, pa kasnije likovna akademija, a ostale prepustimo, odnosno primoramo da crtaju loše slike, da nezadovoljni zbog neuspjeha zauvijek odbace umjetnost ili nesvjesni svoje nesposobnosti uporno nastave i, zaglibivši u svom kiču, ne budu u stanju da stvore kriterij za odnos prema umjetnosti. [...] Treba osjećati svoje vrijeme, treba biti suvremen.«(Janda et al., 1961, 5)

Nasuprot zahtjevima stare škole, koji su bili usmjereni na razvijanje akademskog crtanja i pisanje historicističkih eseja, Jadranka Damjanov je insistirala na odgajanju osjetilne pažnje. Slijedila je svoju ideju prema kojoj se nastava likovne umjetnosti ima ozbiljiti kroz osviještavanje onoga osjetivog u viđenju. Stoga, umjesto da crtaju, učenici su gledali umjetnička djela i pritom istraživali svoj pogled.

Ako se služimo očima da bismo pojmili ono što vidimo, tada nismo u stanju osvijestiti samu djelatnost gledanja. U svakodnevnom se životu služimo očima uglavnom da bismo na osnovi opažaja vidljivog oblika prepoznali predmet i dokučili njegovo značenje, te da bismo znali odgovoriti na pitanje čemu služi predmet koji vidimo; nerijetko pogledom slobodno istražujemo ono osjetivo vidljivog oblika. Ako gledamo u prikaz 5 , vidimo broj pet, a ako gledamo u prikaz $\Delta$, vidimo trokut. Ukoliko vidimo broj pet ili trokut, tada nismo svjesni onoga što vidimo. Da bismo postali svjesni onoga što vidimo, trebamo slobodno istraživati oblik i boju prikaza, ozbiljujući viđenje crne jednake, nejednake krivulje ili uglate krivulje i ravne linije. Naime ono osjetivo u viđenju 
možemo osvijestiti samo onda ako prikaz 5 vidimo kao jednaku krivulju ) koja modulira u uglatu krivulju $<$, odnosno ako prikaz $\Delta$ vidimo kao uglatu krivulju $<$ koja modulira u ravnu liniju -, ne prosuđujući da se radi o broju pet i trokutu.

Činjenica je da očima ne možemo vidjeti niti broj pet niti trokut. Jer su to su pojmovi, dakle ono mislivo, a ne ono osjetivo. Ono osjetivo koje očima opažamo sastoji se, ako je posrijedi crtež/slika, iz oblika koji tvore linije i obojane plohe, a ako je posrijedi skulptura, iz oblika koji tvori masa naspram prostora koji je okružuje.

Teoretski temelj za odgojni čin koji omogućuje takvu vrstu opažanja Damjanova gradi na tragu psiholoških istraživanja percepcije J. J. Gibsona:

»Istraživanje vizualnog započinjemo razjašnjavanjem što vidimo. U razredu pokazujem ovo i na pitanje što vidite, odmah netko vikne kamen, zatim jaje, tren kasnije skulpturu, a netko misli da je šaljivčina i tek je nehotice najprecizniji kada kaže dijapozitiv. Nakon općeg smijeha javlja se jedan glas. A čemu to služi - pita nevino. ... Postupkom odabira odlučili smo da vidimo kamen, jaje, rado bismo se odlučili za nešto kao oprema za domaćinstvo, ali se još kolebamo, pa pitamo - Čemu stvar služi?... može se, međutim, i drugačije odgovoriti. Vidimo zbijenu masu, zgusnutu i zaobljenu puninu (masu) naspram praznine (prostora) koja je okružuje. Navedenim i sličnim riječima upućujemo na dubinsku, univerzalniju razinu opažaja, na kojoj se umjesto odabrana značenja, vide površine, teksture, nagibi, rubovi, boje, međuprostori, likovi. Tu razinu Gibson zove doslovnim opažajem.« (Damjanov, $1991,7-8)^{1}$

Osjet nastaje u umu na osnovi primanja osjetilnog sadržaja izvanjskim podražavanjem osjetila. Gibson se suprotstavlja tradicionalnom shvaćanju koje polazi od pretpostavke da izvana primljeni osjetilni sadržaj ne odgovara u cijelosti osjetu. Naime prema tradicionalnom shvaćanju osjet se ne može u cjelini zgotoviti samo na osnovi osjetila jer je - kao vid razabiranja - svagda ujedno prožet i idejom/pojmom. Utoliko se s jedne strane luči doslovno opažanje (sensus), a s druge strane razabiruće ili poimajuće opažanje (perceptio). No Gibson tvrdi da je

\footnotetext{
${ }^{1}$ Damjanova svoj središnji pojam metodike nastave likovne umjetnosti preuzima od američkog psihologa Jamesa Jeromea Gibsona. Njegov pojam direct perception ne prevodi doslovno s neposredni opažaj, već s doslovni opažaj. Premda je njezin prijevod problematičan, već i stoga što ne odgovara smislu koji ona daje tom pojmu - budući da riječ doslovan značenjem upućuje na ono verbalno, više nego li na ono vizualno - u radu se ipak služimo takvim prijevodom da bismo ostali što usklađeniji s njezinim tekstom.
} 
doslovni vid osjetilnog opažanja sam po sebi dostatan za zgotovljivanje osjeta, pa čak i onog najsloženijeg (Gibson, 1950, 8). ${ }^{2}$

Prema Damjanovi razabirući vid opažanja podrazumijeva svođenje osjetilnog sadržaja na dostupne kategorije. Opažanje prema dostupnim kategorijama ona naziva shematskim vidom opažanja. ${ }^{3} \mathrm{Za} \mathrm{razliku}$ od shematskog vida opažanja, doslovni vid opažanja jest neosviješteno iskustvo. Da bi se osvijestilo doslovno opažanje, valja se odvratiti od prosuđivanja osjetilnog sadržaja prema dostupnim kategorijama (Damjanov, 1991, 8).

Ako ljudi ne promatraju umjetnička djela, rijetko stječu iskustvo opažanja koje je neopterećeno pojmovnim značenjem. Poglavito moderna umjetnost razotkriva iskustvo tekstura, boja, površina, rubova, naime ono doslovno u opažaju (Damjanov, 1991, 191). Stoga možda i nije pretjerano tvrditi da bi bilo teško osvijestiti doslovni vid osjetilnog opažanja mimo radikalnih ostvarenja moderne umjetnosti:

»Moderna je umjetnost, naime, u svojim najradikalnijim ostvarenjima nezastrto pokazala u svim ljudima nazočan doslovni aspekt opažaja.« (Damjanov, 1998, X)

Doslovno opažanje prožeto je likovnošću onoga vidljivog. I Platon ukazuje na tu činjenicu. U Teetetu (163a-d) postavlja sljedeće pitanje: ako ne poznajemo slova stranog jezika jer taj jezik nikada nismo učili, vidimo li mi uopće prikazana slova? (Plato, 1921, 80-87) Platon ističe činjenicu da samo oni koji su uz pomoć jezikoslovaca naučili strani jezik znaju pročitati slova, ali pritom tvrdi da o slovima stranog jezika može imati određeno znanje i onaj koji nije učio jezik. Onaj koji nije naučio strani jezik, a gleda u ispisana slova stranog jezika, doslovno opaža prikaz. On ne može gramatički protumačiti slova, te utoliko ne može vidjeti pojam i ime slova kao onaj koji je naučio strani jezik, ali može vidjeti te tako spoznati linije koje sastavljaju oblik slova i boju.

\footnotetext{
${ }^{2}$ Utoliko je nepotrebno razlikovati sensus i perceptio. Gibson tvrdi da bi se sve teorije percepcije trebale temeljiti na doslovnom opažaju (Bickhard i Richie, 1983, 29-31). Njegova su istraživanja značajno pridonijela razvoju tzv. teorije direktne percepcije (Solso, 1999, 79).

${ }^{3}$ Shematski vid osjetilnog opažanja Damjanova shvaća na način kako je to objasnio američki psiholog Jerome Seymour Bruner. Prema Bruneru je osjetilno opažanje kognitivni proces prepoznavanja onoga vidljivog na osnovi asocijativne moći pamćenja. To znači da čovjek opažajućim umom povezuje osjetilni sadržaj sa sličnim iskustvima koje je pohranio u sjećanju. Ta i takva iskustva Bruner naziva dostupnim kategorijama (accessible categories) (Bruner, 1957, 123-152).
} 
Otuda se može reći da je pismo s jedne strane sredstvo uspostave verbalnog izražavanja, a s druge strane likovni sadržaj koji usmjerava našu pažnju na vidljivi oblik i boju.

Jadranka Damjanov na tom tragu tvrdi da je naša pažnja pri osjetilnom opažanju vizualnih znakova svagda usmjerena na spoznaju verbalnih, a ne likovnih sadržaja (Damjanov, 1991, 191; Damjanov, 2006, 243-256). U nemogućnosti smo uživati u likovnoj ljepoti prikaza, jer nam je pažnja u cijelosti zaokupljena shematizacijom opažaja. Ako je shematski vid opažanja funkcionalan, tada je doslovni vid opažanja $u$ potpunosti neosviješten. Osviještavanje doslovnog vida opažanja podrazumijeva usmjeravanje pažnje na linijske tokove i promjenu boje prikaza.

A da bismo u potpunosti postali svjesni doslovnog vida opažanja, Damjanova tvrdi da je nužno poznavati dinamiku kretanja očiju. ${ }^{4}$ Zato je pod utjecajem Buswellovih i Molnarovih dostignuća iz eksperimentalne estetike elektronistamografski ispitivala kretanja očiju nekolicine ljudi koji su promatrali umjetnička djela, te je tako došla do najvažnijih otkrića za postavljanje metodičko-didaktičkih okvira nastave likovne umjetnosti. ${ }^{5}$

Elektronistamografijom se bilježe titrajni pokreti očiju. Svaki titraj oka jest jedna vidna fiksacija. Potreban je velik broj vidnih fiksacija da bi se ostvarilo viđenje vidljive površine. Svaka vidna fiksacija predstavlja zaustavljanje pogleda privučenog svjetlosnim zrakama koje se odražavaju s vidljive površine. Budući da se elektronistamografski zapis može tumačiti kao crtež, Damjanova zaključuje u Pogledu i slici da oči pri gledanju stvaraju crtež (Prilog 1). Upravo taj crtež koji stvaraju oči shvatila je ona kao ono što odgovara doslovnom vidu opažanja.

Očima stvarani crtež dakako nije osjetilno predočavanje. Dok se predočavanje može shvatiti kao misaono odslikavanje onoga vidljivog, a sama predodžba kao misaoni odslik onoga vidljivog u umu, dotle crtež očiju jest nešto što - stvarano gledajućim okom - niti je u oku ili umu, niti je u onome vidljivom. Prema Damjanovi crtež očiju jest od-

${ }^{4} \gg$ Nužno je uputiti na to kako gledamo. Naše se oči neprestance kreću, skokovito ili posve sićušnim pomacima, jer bez njihovih pokreta ništa ne bismo vidjeli. [...] Našem nesvjesnom pogledu posve je dovoljno nekoliko sekundi da optrči, da registrira to što je pred njim. Druga je stvar koliko smo toga u stanju ili koliko smo toga voljni osvijestiti.« (Damjanov, 1998, 15).

${ }^{5}$ Rezultate ispitivanja objavila je u knjizi Pogled i slika (Hermes, Zagreb, 1996). 
slik mjere koja je skrivena u gledatelju, a koju gledatelj artikulira očima dok pogledom istražuje strukturu likovno-umjetničkog djela.

Ona je elektronistamografskim zapisima pokazala kako gledatelji likovnih umjetnina aktivno učestvuju u umjetnosti stvaralačkom djelatnošću očiju. I onda kada je gledatelj šestogodišnje dijete koje nije svjesno doslovnog vida opažanja, stvara očima crtež sumjeran strukturi umjetničkog djela. Stvaralačka djelatnost umjetnika na osnovi koje se uspostavlja struktura umjetničkog djela, s jedne strane, te stvaralačka djelatnost promatrača umjetničkog djela, na osnovi koje se uspostavlja crtež očiju, s druge strane, poistovjećuju se do te mjere da ih je teško razlikovati:

»Kreativnost promatrača i promatranog očito međudjeluju, poistovjećujući, nadopunjujući se tako da se u nizu zrcala više ne uspiju razlikovati.« (Damjanov, 1996, 13)

Stvaralačka djelatnost očiju (kreativnost promatrača) razvija se prema istom načelu uspostavljanja jedinstva iz mnoštva kao i stvaralačka djelatnost umjetnika. To se načelo u Pogledu i slici poistovjećuje s nadosjetilnom mjerom koja se pojavljuje u osjetilnoj oblasti na mnogolike načine. Mjera proizlazi iz jednog koje Damjanova poistovjećuje - na tragu platoničkog shvaćanja svijeta - s iskonom svega. ${ }^{6}$ Jedno je prema njezinom shvaćanju prajedinstvo apsolutne svijesti koja se rastače u ono vidljivo. Rastače se tako što se - slikovito govoreći - naglo uspinje, rasteže u luku kao uglata linija, stiže do točke gdje se mijenja smjer da bi opisala krug, pa se ispravlja u ravnom toku, iz crvene prelazeći u zelenu, te na mnogolike druge načine. Svi ti načini rastakanja apsolutne svijesti u oblasti onoga vidljivog očituju se kao oblikovanje mjere koja se može nasljedovati slikarskim sredstvima. Likovna počela su sumjerna putanjama očiju. Linija, točka, ploha, boja, tekstura, kao i sve drugo ono doslovno u opažaju, prema Damjanovinu shvaćanju, jesu materijalizirani tokovi apsolutne svijesti u kojoj su sva bića svijeta povezana u svome jedinstvu.

Ako se mjera svijeta očituje kroz sumjerljivo viđenje strukture umjetničkog djela, umjetnost mora biti osjetilno razotkrivanje mjere.

${ }^{6}$ U Metafizici crteža mjeru određuje na sljedeći način: »Mjera je latentno unutra u zaustavljanju i odbijanju zrake i u njenom lomu kao omjer/razmjer. Mjera je prag: pola je u osjetilnom - tu se očituje, pola u nadosjetilnom - odatle potječe. Postoje poznate i nepoznate mjere. Odalačenje od poznatih, što rade moderni umjetnici, ulazak je u polje svih mogućnosti.« (Damjanov, 2006, 312) 
Umjetnik slikotvorstvom nasljeduje mjeru, ozbiljujući jednu od strukturalnih mogućnosti kadra. Njegovo posebno ozbiljenje strukturalne mogućnosti kadra može se shvatiti kao pojavljivanje jedne inačice svijeta. Umjetničko djelo izaziva pogled gledatelja. Stoga gledatelj počinje istraživati očima likovnu strukturu. Time on stvara očima crtež kojim prihvaća mjeru umjetničkog djela koje promatra. U tom trenutku nastaje poistovjećujuće zrcaljenje crteža očiju gledatelja i strukture umjetničkog djela pripadnog umjetniku.

Mjera se na strani gledatelja osjetilno razotkriva svagda različito. Stoga je mnoštvo vidova mjere. Zapravo je onoliko vidova mjere koliko je zasebnih viđenja strukture likovno-umjetničkog djela: gledajuće oko svaki put iznova na zaseban način razotkriva mjeru svojim kretanjem. Ako gledatelj osviještava način na koji prihvaća mjeru, tada on u susretu s umjetničkim djelom nalazi ispunjenje. I samo je u tom slučaju ostvarena svrha umjetničkog odgoja. Umjetnički odgoj omogućuje čovjeku ispunjujuć doživljaj svijeta kroz sebesvjesno opažanje.?

Umjetničkim odgojem čovjek se približava jedinstvu svijesti koja iz temelja svijeta oblikuje svijet kroz osjet. Ono krajnje suprotno od istinskog umjetničkog odgoja jest institucionalizacija shematskog vida osjetilnog opažanja, koja potiče umrtvljivanje osjetila, ne bi li čovjek bez otpora pristajao na mehaničku sliku svijeta:

»Ali naš pogled u krajnjoj funkcionalizaciji jednog do kraja otuđenog svijeta pretvara to golemo bogatstvo u mrtvu shemu zaboravljajući svoju početnu kreativnost (točku palu s neba) i osiromašen, ogoljen, nesretan, jer je nezadovoljen, juri prema nekoj novoj atrakciji na vidiku. [...] Ne treba se zavaravati, čovječanstvo već dugo vrlo sustavno nastoji zastrti doslovni aspekt viđenja i spriječiti osviještenost gledanja/viđenja. Naime, čovjek se, osobito u novije doba, bespoštedno i bezočno koristi vlastitom nesvjesnom sposobnošću dinamike pogleda da bi sebe izložio svakovrsnim utjecajima koji će ostati neosviješteni i tako u krajnjem sebe izrabljuje na razini vrlo suptilnoj jer je nesvjesna. [...] Tako umjetnički odgoj postaje, koliko nemoguć, toliko neophodan za opstanak vrste.« (Damjanov, 1998, X)

Vjerojatno bi tako Damjanova došla do kraja svoje nastavničke karijere i do jedinstvene političke misli, utemeljene na metafizičkoj teoriji umjetnosti, da se odvažila ispitati sve spekulativne mogućnosti svoje

\footnotetext{
${ }^{7} \gg$ Rezultati istraživanja impliciraju da obrazovanje ne treba biti drugo, no osviještavanje onoga što se opaža, a priprema nastavnika iznalaženje puteva i sredstava kako se to nenaporno i učinkovito postiže.« (Damjanov, 2001, 345)
} 
postavke o zastiranju doslovnog vida osjetilnog opažanja. No njoj, prema svemu sudeći, nije bilo do teoretiziranja te vrste, već do utemeljenja nove metodike iz nastave likovne umjetnosti, koja služi odgojnom činu istinskog doživljavanja svijeta. ${ }^{8}$

Tada kad još nije postojao udžbenik za nastavu likovne umjetnosti, koji bi odgovarao ciljevima umjetničkog odgoja kakvog je Damjanova uspostavljala, srednjoškolci su gledali reprodukcije umjetničkih djela, koje je ona imala u velikom broju zahvaljujući svojim dugogodišnjim putovanjima po Europi. Jedina zadaća na satu likovne umjetnosti bila je gledati i razmišljati o viđenome. ${ }^{9}$ Kao što je već rečeno, tada su mnogi, zajedno s Matkom Peićem, zamjerali Damjanovi što u nastavi likovne umjetnosti ne polazi od umjetničke prakse. Na prvu se može činiti kao da je posrijedi bio puko pedagoški spor oko pitanja treba li srednjoškolce na nastavi likovne umjetnosti odgajati bilo kako drukčije do li tako da ih se uči crtati i slikati. Ali riječ je o nečemu puno dubljem - radilo se o čuvanju svima svojstvenog umjetničkog svjetonazora.

Razlog zbog kojeg Matko Peić sumnja u Damjanovinu metodiku, pogrdno nazivajući njezine učenike malim »filozofima« jest isti onaj razlog zbog kojeg on poslijeratno apstraktno američko slikarstvo smatra jednostranošću koja osiromašuje (Peić, 1961b, 5). On u starom slikarstvu, poput slikarstva Thomasa Colea, pronalazi kvalitetu koja nedostaje novom slikarstvu Jaspera Johnsa ili Ada Reinhardta. Za Reinhardtovo Tamno ulje reći će, primjerice, da to »nije ništa drugo nego od jednog kraja do drugog monotonom crnom bojom pokrivena ploha« (Peić, 1961b, 5). Prema njegovom shvaćanju takvo slikarstvo naliči eksperimentima u fizikalnom laboratoriju; ono nema nikakve veze $\mathrm{s}$ pravim slikarstvom.

\footnotetext{
${ }^{8}$ Damjanovino istraživanje umjetnosti filozofkinja Gordana Bosanac shvaća kao eksperimentalno utemeljenje metafizike (Bosanac, 1998, 222-228).

${ }^{9}$ Objavljivanje udžbenika s više od tisuću reprodukcija bila je i više nego poželjna prekretnica u izvedbi nastave likovne umjetnosti. Damjanova je zgotovila udžbenik te ga je objavila u dva sveska 1971/72. godine u izdanju Školske knjige iz Zagreba. Oba sveska Likovne umjetnosti doživjela su do danas preko trideset izdanja. Prvi svezak strukturirano izlaže osnove slikarstva, kiparstva i arhitekture, a drugi svezak izlaže povijest umjetnosti. Dok prvi svezak služi učenju likovnog jezika, drugi svezak svoju svrhu iznalazi u stjecanju ahistorijskog iskustva umjetnosti. Osim Likovne umjetnosti 1 i 2, Damjanova je zajedno s Dubravkom Jandom i Marcelom Bačićem napisala Likovnu umetnost (Pokrajinski zavod za izdavanje udžbenika, Novi Sad 1975,), te s Dubravkom Jandom Likovnu kulturu (Zavod za izdanje udžbenika, Novi Sad 1988.).
} 
Činjenica je da moderna umjetnost postaje sve više apstraktna, pretpostavljajući oblik sadržaju, te se odriješuje od narativnog likovnog motiva i prikazivanja životne stvarnosti. Takvu umjetnost poglavito veličaju predstavnici formalizma u umjetnosti. Prema njima ono odredbeno za umjetninu jesu vizualni aspekti likovne strukture: - tekstura, kakvoća poteza kista, širina i duljina linija, koloritska kvaliteta. Matko Peić se ne protivi formalističkom pristupu, dočim nije sklon pretjeranom formalizmu u umjetnosti:

»Jedan dio modernih umjetnika u želji da istakne nadmoć likovnog teksta [likovne forme] nad motivom, u likovnom djelu ide dotle da čak negira motiv. Međutim, bilo bi pogrešno misliti da se umanjivanjem kvantitete motiva u likovnom djelu automatski diže kvaliteta likovnog teksta u njemu, također bi bilo naivno tvrditi da je svaka apstraktna slika ili kip koji je lišen motiva uvijek i umjetničko djelo apstraktnog pravca.« (Peić, 1968, 229)

Prema svemu sudeći Peić smatra da apstraktni američki slikari pretjeruju u naglašavanju likovne forme, pa stoga uopće ne stvaraju kvalitetna umjetnička djela. Unatoč činjenici da pretpostavljaju oblik sadržaju, nedostaje im snage kojom mogu pretvoriti svoju emociju u likovna počela. Forma likovnog djela ne smije biti drugo do li izraz umjetnikove ličnosti koja odražava duh jednog vremena, a novim američkim slikarima, više nego starima, nedostaje te snage. Oni su u emocionalnom pogledu osiromašeni. Naime Peić prihvaća formalizam u umjetnosti ukoliko je ekspresivistički utemeljen. ${ }^{10}$ A izraziti predstavnici ekspresivističke teorije uglavnom su naklonjeniji starijoj umjetnosti.

$\mathrm{Na}$ početku dvadesetog stoljeća mnogi teoretičari umjetnosti ističu da se estetičko iskustvo pripadno modernoj umjetnosti u bitnom razlikuje od estetičkog iskustva pripadnog umjetnosti devetnaestog stoljeća. Moderna umjetnost je mnoge nagnala na preispitivanje biti umjetničkog djela. Postaje upitnim postoji li uopće zajednička crta između apstraktnog Maljevičeva crteža i realističnog Courbetova prikaza života

${ }^{10}$ Matko Peić u Pristupu likovnom djelu polazi od formalizma u umjetnosti: »Zbog toga je likovno djelo samo onda kvalitetno kada u njemu likovni tekst nadvladava motiv, a likovno je nekvalitetno kada je likovni tekst ispod motiva ili, kao što je kod likovnog kiča, kada ga uopće nema.« (Peić, 1968, 12-13) No zacijelo želi nadvladati puki formalizam, naglašavajući psihologistički pristup umjetnosti, na tragu ekspresivističke teorije: »U likovni tekst: u crtu, u boju i u volumen slikar, kipar i arhitekt unose sebe, tako da je tačna tvrdnja francuskog književnika Buffona [Bufona]: Stil - to je čovjek. Slikarstvo Nicolea Pousina [N. Pusen] jest slikarstvo sređenog, a slikarstvo P. Paula Rubensa slikarstvo strastvenog čovjeka.«(Peić, 1968, 13) 
seljaka i radnika. Prema Mauriceu Denisu, prethodniku formalističke teorije umjetnosti, tradicionalna umjetnost (naturalistička) jest objektivna preobrazba prirode, a moderna umjetnost (anti-naturalistička) jest subjektivna preobrazba prirode:

»Umjetnost više nije puko vidna senzacija koju bilježimo, fotografija prirode, sofisticirana što je više moguće. Naprotiv, ona je kreacija našeg duha, koju iznuđuje priroda. Uobrazilja ponovno postaje, kao u Baudelairea, kraljica osjetilnih moći. Tako oslobađamo našu osjetilnost. [...] Umjetnost postaje, prije nego li kopija, subjektivna preobrazba prirode.« (Denis, 2001, 50)

Prema njemu umjetnik može prikazivati prirodu na dva načina. (1) Može slikati tako da slikarskim sredstvima nasljeduje osjetilni sadržaj, nesvjestan subjektivnog doživljaja osjetilnog podražavanja, (2) ili - postajući svjestan osjetilnog podražavanja - može likovnim elementima nasljedovati doživljaj iskustva koje je stekao osjetilnim podražavanjem prirode. Umjetničko istraživanje osjetilnog podražavanja oslobađa umjetnikovu osjetilnost do te mjere da on - učestvujući duhom u vječnim zakonima ideje ljepote - likovno prikazuje stvaralačku djelatnost uobrazilje. $^{11}$

Denisovo, jednako kao i neko ekspresivističko shvaćanje umjetnosti, ili pak pretjerano formalističko, zasniva se na stvaralačkom iskustvu umjetnika: - umjetnost može razumjeti najviše onaj koji je iskusan u umjetničkom proizvođenju. ${ }^{12}$ To potvrđuje i Clive Bell, koji je bio jedan od utjecajnijih predstavnika teorije formalizma u umjetnosti. Prema njemu figurativno (reprezentacijsko) slikarstvo jest znak slabosti umjetnika: umjetnik koji naglašava narativni sadržaj nije pravi umjetnik jer ne zna omogućiti gledatelju čisto estetičko iskustvo. Budući da to prema Bellu znači kako samo pravi umjetnik umije kroz značajnu formu prevesti svoj osjećaj u likovno umjetničko djelo (Bell, 1914, 7-11), i formalističko shvaćanje umjetnosti nasljeduje uvjerenje da ono bitno umjetnosti leži u umjetniku.

Stoga bez obzira je li netko naklonjeniji starijoj ili novijoj umjetnosti, ekspresivističkoj ili formalističkoj teoriji umjetnosti, svi će se oni jednako složiti u tome da izvorno osjetiti umjetnost može samo netko

${ }^{11}$ Takvo se shvaćanje umjetnosti uvelike oslanja na formalizam Immanuela Kanta u vidu prosudbe ljepote (Kant, 2006, 47-105).

${ }^{12}$ Otuda potreba da se poznate i slavne umjetnike intervjuira u vezi njihova shvaćanja umjetnosti, ne bi li se tobože na taj način mogli i oni koji nisu umjetnici što vjerodostojnije približiti ideji umjetnosti. 
tko umije nešto ostvariti u umjetnosti. Moglo bi se stoga reći kako svi jednako smatraju da je umjetnost za umjetnike. ${ }^{13}$ Pa kada Peić u osvrtu na srednjoškolce koji doživljavaju umjetnost na Damjanovin način daje prednost crtanju i slikanju na nastavi, a ne gledanju i razmišljanju, tada on, zapravo, potvrđuje jedan umjetnički svjetonazor koji polazi od toga da je likovni jezik fenomenološka metoda koja pretpostavlja mogućnost shvaćanja stvaralačke djelatnosti umjetnika; ne i stvaralačke djelatnosti gledatelja. Utoliko žaleći za satovima crtanja, on ne žali za starim vrijednostima, nego brani jedan zajednički stav o umjetnosti u koji nitko ne bi trebao dvojiti, te upozorava na negativne posljedice likovnog obrazovanja koje će uslijediti ako se prihvati Damjanovina metoda. ${ }^{14}$

Damjanovini učenici zauzimali su nov pristup umjetnosti, prema kojemu se umjetničko stvaranje ne svodi samo na stvaralačku djelatnost umjetnika. Naime i gledatelji umjetnina aktivno učestvuju u umjetnosti stvaralačkom djelatnošću svojih očiju. A koliko je Damjanonovin pristup nešto radikalno novo, možda ponajbolje kazuje Meštrovićev tekst na koricama njezine knjige Pogled $i$ slika:

»Jadranka Damjanov je svojom predanošću putu koji krči u području nepoznatog/nespoznatog ne samo začetnik u nas, nego i jedan od rijetkih zagovornika onog nadolazećeg pomaka, ako ne i prevrata/obrata, koji se u suvremenom mišljenju svijeta tek naslućuje.«

Ako bi se htjelo nekako razumjeti oduševljenje umjetnošću koje su izražavali Damjanovini učenici, koje je bilo poprilično zabrinjavajuće Matku Peiću, te ako bi se htjelo na tom tragu bolje razumjeti smisao Damjanovina umjetničkog odgoja, potrebno je prethodno uočiti razliku

${ }^{13} \mathrm{Na}$ tom tragu José Ortega y Gasset zaključuje: »Evo zašto moderna umjetnost dijeli općinstvo na dva razreda, na one koji je razumiju i na one koji je ne razumiju - tj. na one koji su umjetnici i na one koji to nisu. Nova umjetnost jest umjetnost za umjetnike.«(Ortega y Gasett, 2007, 23)

${ }^{14}$ Nakon uvođenja Katedre za metodiku nastave likovne umjetnosti na Odsjek za povijest umjetnosti Filozofskog fakulteta u Zagrebu, Damjanova je nastojala - kao nositeljica tog kolegija - da na najprimjereniji način usustavi svoju metodiku. Njezina knjiga Vizualni jezik i likovna umjetnost (Školska knjiga, Zagreb 1991.) predstavlja konačni rezultat njezinih istraživanja umjetnosti. U svojem kritičkom osvrtu na tu knjigu Matko Meštrović piše: »Uzme li se u obzir u kojoj je mjeri tradicija teoretizacije o likovnosti bila opterećena literarno historicističkim esejizmom i/ili stilsko analitičkim formalizmom, i koliko je iz takvog pristupa izostajala i elementarna znanstvena obaviještenost o fenomenologiji vizualnosti..., onda će tek biti jasno koliki je rezultat postignut u objašnjenjima kategorija koje čine okosnicu ove knjige.« (Meštrović, 1992, 64) 
između formalističkog i Damjanovina isticanja onoga što gledatelj u pogledu ima osvijestiti ako želi steći ispunjujuće iskustvo umjetnosti. Blizak Damjanovi bio je u svojim promišljanjima José Ortega y Gasset, koji pokušava objasniti umjetnost u okvirima geometrijske optike:

»Evo jednog vrlo jednostavnog optičkog problema. Da bismo vidjeli neku stvar, moramo svoje vidne organe prilagoditi na određen način. Ako ta prilagodba nije kakva treba, stvar ćemo vidjeti nerazgovijetno ili je uopće nećemo vidjeti. Uzmimo vrt koji se vidi kroz prozor. Gledajući vrt, mi prilagođavamo oči tako da vidna zraka kroz okno putuje bez zadržavanja i počine na grmlju i cvijeću. Dok smo usredotočeni na vrt i dok je naša vidna zraka upravljena na nj, mi ne vidimo prozor nego jasno gledamo kroz njega. Ali mi možemo, ako nas je volja, zanemariti vrt i, povlačeći vidnu zraku, zadržati je na prozoru. Tada nam vrt nestaje s očiju... Dakle, gledati vrt i gledati prozorsko okno dvije su nespojive radnje, koje isključuju jedna drugu jer zahtijevaju različitu prilagodbu. Isto tako i umjetničko djelo iščezava s očiju promatraču koji u njemu traži samo dirljivu sudbinu Ivice i Marice, ili Tristana i Izolde... [...] Ali, nema mnogo ljudi kadrih da prilagode svoje opažajne organe i na okno i na onu prozirnost koja je umjetničko djelo. Umjesto toga, oni gledaju ravno kroz njega i uživaju u ljudskoj stvarnosti kojom se djelo bavi.« (Ortega y Gasett, 2007, 19-20)

Ono što Damjanova naziva shematskim vidom osjetilnog opažanja zacijelo odgovara onome što Ortega y Gasset opisuje kao prilagođavanje osjetila narativnom sadržaju umjetničkog djela, dok ono što ona naziva doslovnim vidom osjetilnog opažanja odgovara onome što Ortega y Gasset opisuje kao prilagođavanje osjetila likovnoj strukturi djela. Ako čovjek opaža likovnu strukturu, tada on prema Ortega y Gassetu nije prilagođen uživanju u narativnom sadržaju. Stoga slijedi da su moguća dva estetička iskustva, pripadna dvama oprečnim senzibilnostima. Jedna je senzibilnost umjetnička; druga je ljudska. ${ }^{15} \mathrm{~S}$ umjetničkom senzibilnošću osjetila su namjerena na likovnu strukturu, a s ljudskom senzibilnošću na narativni sadržaj djela. Tako se objašnjava težnja moderne umjetnosti, kojoj pripada umjetnička senzibilnost, da se umjetnost pročisti od prikazivanja ljudske životne stvarnosti.

Damjanova pak polazi od činjenice da je nemoguće ako netko opaža narativni sadržaj likovnog djela da ne opaža likovnu strukturu.

${ }^{15}$ Tako i kod Clivea Bella razlikujemo (1) istinsko estetičko iskustvo ovisno o formi sastavljenoj od linija, boja i njihovih odnosa, koja zadovoljava umjetničke interese (Significant Form) i (2) lažno estetičko iskustvo ovisno o narativnom sadržaju koji zadovoljava puko ljudske interese (Bell, 1914, 2-8). 
Moguće je samo - što je odlučujuće za razumijevanje njezinog shvaćanja umjetnosti - da netko bude nesvjestan opažanja likovne strukture. Prema njoj je besmisleno tvrditi da moderna umjetnost teži pročišćenju umjetnosti od ljudske senzibilnosti (narativnog sadržaja).

Kao što smo nesvjesni djelatnosti disanja, hranjenja, rasta tijela, tako smo nesvjesni i doslovnog opažanja. Premda osviještavanjem disanja i hranjenja možemo steći uvid u zakonitosti prirode, te tako iskusiti viši pojam života, time se ne odrješavamo od svakodnevnog iskustva životne stvarnosti. Naprotiv, moguće je da će nam šira svijest o prirodnim procesima života omogućiti kvalitetnija svakodnevna životna iskustva.

U usporedbi s tim, kada netko zahvaljujući umjetničkom odgoju postane svjestan opažanja likovne strukture, može on bolje razumijevati i shematski vid opažanja. Naime tek kada netko osviještava doslovno opažanje, može razumjeti da je prosuđivanje narativnog sadržaja likovno-umjetničkog djela rezultat opažanja prema dostupnim kategorijama. Pritom ga ništa ne priječi da produbi značenje narativnog sadržaja. Upravo to čini Damjanova kada iz dubine mogućih značenja koja proizlaze na osnovi narativnog sadržaja razotkriva prema dostupnim kategorijama arhetipske suprotnosti svijeta. ${ }^{16}$

Ne treba stoga tvrditi da se prema Damjanovi uopće ne trebaju prihvaćati vrijednima umjetničke tvorbe koje prenaglašeno sugeriraju značenje prizora prema dostupnim kategorijama, premda će, bez dvojbe, ispravan doživljaj takvih umjetnina biti redovito otežan, a možda i sasvim nemoguć bez primjerenog odgoja pažnje.

Budući da Damjanova ne tvrdi da umjetnička tvorba treba biti što savršenije prožeta značajnom formom ne bi li se ostvarilo istinsko iskustvo umjetnosti, bilo bi pogrešno misliti da je njezino shvaćanje umjetnosti samo jedna varijanta formalizma u umjetnosti:

(1) Prema formalističkom shvaćanju samo se moderna umjetnost može shvatiti kao izraz čiste umjetnosti. Naturalistički i romantički stil devetnaestog stoljeća više od ijednog drugog umjetničkog stila ispunjeni su izvanumjetničkim sadržajem koji uprizoruje određena značenja narativnog karaktera te ve-

${ }^{16}$ Poglavito u Metafizici crteža analizira narativni sadržaj umjetnine u vidu arhetipskih značenja. Gordana Bosanac primjećuje da takva Damjanovina analiza »sadrži začudan i jedinstven misaoni tretman koji iz značenjskog vacuuma uspijeva predmet staviti u igru oživljavanja značenjske sveukupnosti« (Bosanac, 1998, 226). 
liča ljudske radosti i žalosti. Stoga povijest umjetnosti zapravo nije drugo nego povijest sastavljena iz uspona i padova uspostavljanja čiste umjetnosti.

(2) Prema Damjanovinu shvaćanju svaki stil u umjetnosti jest izraz čiste umjetnosti. Naturalistički i romantički stil devetnaestog stoljeća više od ijednog drugog umjetničkog stila skrivaju mjeru, no to ne znači da su imalo odriješeni od mjere. Povijest umjetnosti je zapravo razvoj širenja ljudske svijesti. ${ }^{17}$

Ako osviještavamo doslovno opažanje, tada dok gledamo u prikaz $\Delta$ nećemo htjeti vidjeti samo trokut, jer ćemo znati da je ono što doslovno vidimo uglata krivulja < koja modulira u ravnu liniju -, a dok gledamo u prikazu 5 nećemo htjeti vidjeti samo broj pet, jer ćemo znati da je ono što doslovno vidimo jednaka krivulja ) koja modulira u uglatu krivulju $<$.

Ako smo svjesni onoga što doslovno opažamo, i ako samo na to usredotočujemo pažnju, tada ne pokušavamo nad tim sprovesti svoju volju i vidjeti to prema nama dostupnim kategorijama. A takvo nas gledanje približava duhovnom iskustvu apsolutne svijesti:

»Maljevičevu sliku čitamo u prvom redu s apsolutne, apstraktne razine i izjave koje takav pristup potvrđuju supremacija osjeta, ne slikam kvadrat nego supremaciju osjeta ubrajamo u površinsku relativnu razinu crteža. Maljevičev termin osjet lako prevodimo na Gibsonov doslovni opažaj i gledajući crtež vidimo materijalizaciju doslovnog opažaja, svih malih promjena u svjetlini, cijeli apstraktni apsolutni svijet...«(Damjanov, 2006, 272)

Na Maljevičevu crtežu Crni kvadrat (1913.) nema narativnog sadržaja. No to ne znači da je taj crtež čišća umjetnost od, primjerice, Courbetovih naturalističkih prikaza iz života seljaka i radnika:

»Usmjeravamo pažnju ponovno na Courbetovu sliku, ali sad viđenu iz apsolutnog, i prodiremo pogledom do igre različitih faktura (posve glatka - pozadina, gusti krpom razmazani dio - srednji plan, špahtlom nabacana boja - prednji dio).«(Damjanov, 2006, 272)

${ }^{17} \mathrm{O}$ povijesti umjetnosti kao razvoju i širenju ljudske svijesti Damjanova poglavito raspravlja u Metafizici crteža. Tamo na jednom mjestu izričito kritizira formalističko shvaćanje umjetnosti: »Europska umjetnost, od svog prvog stila romanike do moderne, na čudesan način tematizira sva za čovjeka moguća stanja svijesti, sve po redu, do njihovog ostvarenja u jedinstvu apstraktnog modernog djela. [...] Današnja nastojanja da modernu svedu na jedan, zapravo nadiđen stil odaju nerazumijevanje biti moderne, dapače i biti umjetničkih transformacija.« (Damjanov, 2006, 198-199) 
Svaka pojedina likovna tvorba, bez obzira pretpostavlja li narativni sadržaj obliku ili pretpostavlja oblik narativnom sadržaju, jest svojevrsna koreografija priređena za naše oči. Osviještavamo li doslovni opažaj, tada i u najmanjem skoku oka koje se kreće po detaljima likovne strukture ostvarujemo istinski doživljaj cijelog svijeta. Gledamo li na taj način, ulazimo u oblast cjelokupnih mogućnosti ispoljavanja jedinstva svijeta, koja se razotkriva ozbiljivanjem strukturalnih mogućnosti kadra. To u konačnici znači da u dubini pogleda usmjerenog na likovnu umjetninu vlada jedinstvo svijesti. A shematsko opažanje to i takvo jedinstvo ne može izgnati iz svijeta.

Koliko god da umjetničkom djelu upravo formalni likovni elementi omogućuju istinsko estetičko iskustvo, bilo bi pogrešno misliti da se bit umjetnosti razotkriva kroz likovnu formu. Shvaćanje biti umjetnosti u onoga koji se bavi istraživanjem likovne forme, jednako kao i u onoga koji se, poput Matka Peića, bavi istraživanjem slikarske kvalitete poistovjećene sa snagom pretvaranja emocija u likovni jezik, može biti površno, te njihovo estetičko iskustvo može ostati oslabljeno ako su metafizički momenti rastakanja apsolutne svijesti kroz likovna počela u vidljivi svijet ostali neshvaćeni.

Damjanova je svojim shvaćanjem umjetnosti nastojala dublje prodrijeti u smisao umjetničkog odgoja. Umjetnički odgoj, kako ona to vidi, ne bi trebao pristajati na obrazovanje koje polazi od metoda učenja crtanja i slikanja. Metode istinskog umjetničkog odgoja odgovaraju zahtjevima osjetilnosti koja je do te mjere slobodna da pripada svijesti koja sobom odražava sveprožimajuću kreativnost prirode. Oni koji se na taj način odgajaju žele za sebe oživjeti i produbiti doživljaj cjelovitosti svijeta. Stoga je za njih umjetnički odgoj nastojanje oko samih sebe i svog samorazvitka u smjeru viđenja cijelog svijeta već i u njegovom najsićušnijem dijelu. Drukčije rečeno, umjetnički odgoj kroz osjet čuva jedinstvo duha u svijetu. ${ }^{18}$

${ }^{18}$ Jadranka Damjanov je pred kraj svoje nastavničke karijere osnovala i slobodnu školu radioničkog tipa u Centru za kulturu i obrazovanje u Zagrebu, gdje je studente povijesti umjetnosti, ali i druge ljubitelje umjetnosti, poticala na kreativno istraživanje umjetnosti. Sve vježbe te vrste opisala je i objavila u obliku priručnika koji je naslovila Umjetnost Avantura (Hermes, Zagreb 1998.). Kasnije su i drugi nastavnici likovne umjetnosti, po uzoru na Umjetnost Avanturu, izrađivali slične vježbe na svojim satovima, te su ih potom i objavljivali. Da bi izvođenje takvog tipa nastave iz likovne umjetnosti u potpunosti bilo olakšano svim srednjoškolskim nastavnicima, Jadranka Damjanov još je napisala i Priručnik za nastavnike, koji je izdala Školska knjiga u Zagrebu 2002. godine. Nastavnici u Hrvatskoj i dalje objav- 
Prilog 1. Primjer elektronistamografskog zapisa (Damjanov, 1996, 56)

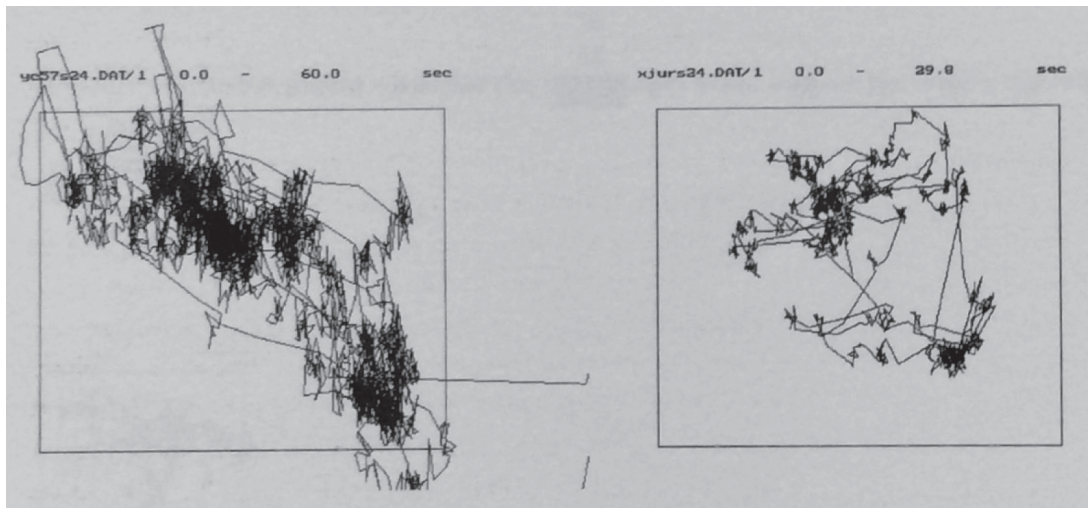

\section{Literatura}

Bell, Cline (1914), Art, New York: Frederick A. Stokes Company.

Bickhard, Mark, H. i Richie, Michael, D. (1983), On the Nature of Representation. A Case Study of James Gibson's Theory of Perception, New York: Praeger Publishers.

Bosanac, Gordana (1998), »Fizika i metafizika pogleda«, Filozofska istraživanja, 1(18), str. 221-228.

Bruner, Jerome, S. (1957), »On perceptual readiness«, Psyhological Review, 64(2), str. 123-152. doi: http://dx.doi.org/10.1037/h0043805

Damjanov, Jadranka (1971), Likovna umjetnost 1, Zagreb: Školska knjiga.

Damjanov, Jadranka (1972), Likovna umjetnost 2, Zagreb: Školska knjiga.

Damjanov, Jadranka (1991), Vizualni jezik i likovna umjetnost, Zagreb: Školska knjiga.

Damjanov, Jadranka (1996), Pogled i slika, Zagreb: Hermes.

Damjanov, Jadranka (1998), Umjetnost Avantura/Art Adventure, Zagreb: Hermes.

ljuju istovrsne vježbe na Internetu pod naslovom Metodičke sintagme i paradigme. Do sada je na toj internetskoj stranici objavljeno više od petsto vježbi te oko 3000 reprodukcija. A Gordana Košćec i Ida Mati izradile su po istom didaktičko-metodičkom obrascu udžbenike za predškolsku i školsku djecu, naslovljene Točka, crta, svijet (Profil, Zagreb 2008.). 
Damjanov, Jadranka (2001), »Prošlost, sadašnjost i budućnost likovnog obrazovanja u nas«, u: Pelc, Milan (ur.), Zbornik 1. kongresa hrvatskih povjesničara umjetnosti, Zagreb: Institut za povijest umjetnosti, str. 343-346.

Damjanov, Jadranka (2006), Metafizika crteža, Zagreb: Sipar.

Damjanov, Jadranka; Janda, Dubravka i Bačić, Marcel (1975), Likovna umetnost, Novi Sad: Pokrajinski zavod za izdavanje udžbenika.

Damjanov, Jadranka i Janda, Dubravka (1988), Likovna kultura, Novi Sad: Zavod za izdanje udžbenika.

Denis, Maurice (2001), »From Gauguin and van Gogh to Neo-Classicism«, u: Harrison, Charles i Wood, Paul (ur.), Art in Theory: 1815-1900. An Anthology of Changing Ideas, Oxford: Blackwell, str. 47-53.

Gibson, James, J. (1950), The Perception of the Visual World, Boston: Houghton Mifflin.

Janda, Dubravka; Bonačić, Vlasta; Mihelić, Stanka i Vujičić, Ante (1961), »Bojište mišljenja: Mi nismo mali filozofi... «, Telegram. Jugoslovenske novine za društvena i kulturna pitanja, 2(88), 29. prosinca, str. 2.

Kant, Immanuel (2006), Kritik der Urteilskraft, Hamburg: Felix Meiner Verlag.

Košćec, Gordana i Mati, Ida (2008), Točka, crta, svijet, Zagreb: Profil.

Meštrović, Matko (1992), »Prema sebesvjesnom opažanju«, Kontura, 8, str. 64.

Ortega y Gasett, José (2007), Dehumanizacija umjetnosti, Zagreb: Litteris.

Peić, Matko (1961a), »U zagrebačkim salonima i galerijama: Izložba dokumenata likovne umjetnosti u nastavi«, Telegram. Jugoslovenske novine za društvena i kulturna pitanja, 2(81), 10. studenog, str. 5.

Peić, Matko (1961b), »Suvremeno američko slikarstvo - Jednostranost koja osiromašuje«, Telegram. Jugoslovenske novine za društvena i kulturna pitanja, 2(84), 1. prosinca, str. 5.

Peić, Matko (1968), Pristup likovnom djelu, Zagreb: Školska knjiga.

Plato (1921), Theaetetus; Sophist, London: (Loeb Classical Library) William Heinemann.

[PV] Prosvjetni vjesnik - službeni organ savjeta za prosvjetu NR Hrvatske (1960), »Nastavni plan i program za gimnaziju. Umjetnost«, 13(8), 8. srpnja, str. 173-175.

Solso, Robert, L. (1999), Cognition and the Visual Art, Cambridge: MIT Press. 


\title{
JADRANKA DAMJANOV'S PEDAGOGICAL METHODOLOGY - BECOMING AWARE OF DIRECT PERCEPTION
}

\begin{abstract}
Marko Tokić
In this paper the purpose of Jadranka Damjanov's approach to visual arts education and her understanding of art are mainly discussed. The starting point for getting an insight into the purpose of Damjanov's pedagogical methodology of art history is discussion between Matko Peic and Damajnov's students started in Telegram newspapers in 1961. According to Damjanov's opinion the purpose of visual arts education is to become aware of direct perception. Results of Electronystagmography - a diagnostic test that records involuntary eye movements while observing works of art-favors her theory. Damjanov believes that art is sensuous disclosure of measurement accomplished not just by artist but by percipient as well. In that way she distances herself from common theories of art.
\end{abstract}

Key words: perception, eyes, electronystagmography, nurture (education), awareness, art 